\title{
Improved Life Style of Members through Self-Help Groups
}

\section{Sukanya $\mathbf{M}^{\star}$}

Department of Management Studies, Sreenidhi Institute of Science and Technology, Yamnampet, Ghatkesar, Telangana, India

\begin{abstract}
A Self-Help Group (SHG) is a village-based financial intermediary committee usually composed of 10-20 local women or men. A mixed group is generally not preferred. Most self-help groups are located in India, though SHGs can be found in other countries, especially in South Asia and Southeast Asia. Members make small regular savings contributions over a few months until there is enough capital in the group to begin lending. Funds may then be lent back to the members or to others in the village for any purpose. In India, many SHGs are 'linked' to banks for the delivery of micro-credit.
\end{abstract}

Keywords: Self-help; Capital; Self-employed; Self-earning; Socioeconomic; Micro-credit

\section{Introduction}

A self-help group may be registered or unregistered. It typically comprises a group of micro entrepreneurs having homogeneous social and economic backgrounds; all voluntarily coming together to save regular small sums of money, mutually agreeing to contribute to a common fund and to meet their emergency needs on the basis of mutual help. They pool their resources to become financially stable, taking loans from the money collected by that group and by making everybody in that group self-employed. The group members use collective wisdom and peer pressure to ensure proper end-use of credit and timely repayment. This system eliminates the need for collateral and is closely related to that of solidarity lending, widely used by micro finance institutions. To make the book keeping simple, flat interest rates are used for most loan calculations.

\section{Review of Literature}

In the year 2012 the study states SHG are younger than other firms. SHG group enterprises are larger than other and they are successful in their business. Their profit, net worth and sales value more progressive than non-SHG entrepreneurs. SHG women entrepreneurs are the aware of opportunities available to them economic status, self-worth, selfconfidence and social status of women entrepreneurs are the variable that define empowerment of women. Women entrepreneur in SHG are more empowered then non-SGH. Self-discipline is maintained in the groups [1].

The study states that in Tirunelveli district middle age (30-45) group women are entrepreneurs. They are doing business with less investment and at low risk. Mostly married women are doing business because supplement their family income, providing good life for their children and self-earning independent. More entrepreneurs are belonging to backward caste.

In the year 2012 in the study states that more respondents are occupying agricultural activity most of women are 40-50 age group are the members. Half of the respondents engaged in various income generating activities belongs to SCIST. Reasons of women joining SHG is giving financial support to their family. According to availability of resources and opportunities they are doing the income generating activities like tailoring, nursing and dairy [2].

The Study states that member of SHG has no primary education but they are able to read and write. Members of the group are married, unmarried and widows. To raise status in society is the prime reason for joining SHG to promote income generating activities, to get loan, to promote savings, to maintain household expenditure they are joining in SHG. Majority of respondents are belongs to the groups which were established 5 yr. ago. After joining SHG the women are economically and socially empowered [3].

The study states that rural women had a very low level of education. Women respondents earned an amount of Rs.20, 000 on an average annually from the various sources. By doing small income generating activities they can help the family for financially, through the help of self-help groups.

The study has revealed that different agro processing SHGs, classified under four groups of fish processing, copra processing, powder makes and ready-to-eat items making, behave differently in their socio-economic and group characters. The article says that performance of SHGs is influenced more by the experience indirectly by the age rather than the education level. It is revealed that group stability is influenced. Analysis has revealed that significant socioeconomic characters that contribute towards group performance in general, are management-orientation [4].

\section{Research Methodology}

Topic of the research study" A studies on life style of women members through self-help groups". The research design in this study will incorporate the following steps, which the researcher has to deal with:

a) A brief study done with reference to microfinance

b) The researcher had to have a critical analysis of similar studies, formulate research questions. These research questions will lead to the problem statements.

\section{Objectives of the study}

To study improved life style of women members in self-help groups.

\section{Hypotheses formulation with reference to the objectives}

H1: Self-help group shows positive impact on improved life style of women members.

*Corresponding author: Sukanya M, Department of Management Studies, Sreenidhi Institute of Science and Technology, Yamnampet, Ghatkesar, Telangana India, Tel: 9246274791; E-mail: sukanyamadasu@rediffmail.com

Recieved March 27, 2018; Accepted May 28, 2018; Published June 06, 2018

Citation: Sukanya M (2018) Improved Life Style of Members through Self-Help Groups. J Entrepren Organiz Manag 7: 238. doi: 10.4172/2169-026X.1000238

Copyright: @ 2018 Sukanya M. This is an open-access article distributed under the terms of the Creative Commons Attribution License, which permits unrestricted use, distribution, and reproduction in any medium, provided the original author and source are credited. 
Citation: Sukanya M (2018) Improved Life Style of Members through Self-Help Groups. J Entrepren Organiz Manag 7: 238. doi: 10.4172/2169026X.1000238

Page 2 of 2

The methodology that would be adopted to address the earlier objectives and test the hypotheses formulated is as follows:

Data requirement and sources: Data is collected from the Micro finance office at Bibinagar village and SHG member in Bibinagar village. While preparing the questionnaire, the objectives are the hypotheses to test will be taken into account. The data will relate to the demographic variables $[5,6]$.

Identification of a sampling design in case of a survey: The population in this study could be city, an area segment. Therefore, the size of the representative sample will be decided and proper sampling process will be worked out. Specification of statistical techniques Univariate tools such as tables, charts could be used to introduce the sample characteristics to the reader. Bivariate tool such as anova could be used to highlight the relationship between the variable in the sample (Table 1).

Above Table 1 shows that out of 6 variables 5 variables are greater

\begin{tabular}{|c|c|c|c|}
\hline S. No & & & Sum of Squares \\
\hline \multirow[t]{3}{*}{1.} & \multirow[t]{3}{*}{ Do you have gas at home } & Between Groups & 0.088 \\
\hline & & Within Groups & 4.662 \\
\hline & & Total & 4.750 \\
\hline \multirow[t]{3}{*}{2.} & \multirow[t]{3}{*}{ Do you have TV at home } & Between Groups & 0.004 \\
\hline & & Within Groups & 0.986 \\
\hline & & Total & 0.990 \\
\hline \multirow[t]{3}{*}{3.} & \multirow[t]{3}{*}{ Do you have minimum gold at home } & Between Groups & 0.100 \\
\hline & & Within Groups & 13.210 \\
\hline & & Total & 13.310 \\
\hline \multirow[t]{3}{*}{4.} & \multirow[t]{3}{*}{ Do you have fan at home } & Between Groups & 0.000 \\
\hline & & Within Groups & 0.000 \\
\hline & & Total & 0.000 \\
\hline \multirow[t]{3}{*}{5.} & \multirow[t]{3}{*}{ Do you have two wheeler at home } & Between Groups & 2.558 \\
\hline & & Within Groups & 74.082 \\
\hline & & Total & 76.640 \\
\hline \multirow[t]{3}{*}{6.} & \multirow[t]{3}{*}{ Do you have cell phone } & Between Groups & 0.887 \\
\hline & & Within Groups & 74.023 \\
\hline & & Total & 74.910 \\
\hline
\end{tabular}

Table 1: Impact of life style of women members in SHG ANOVA.

than $\mathrm{P}$ variable i.e. 0.05 have null hypothesis rejected alternative hypothesis accepted. This shows that there is significance difference between groups $[7,8]$.

\section{Findings and Conclusion}

The study was conducted for Microfinance members in the area of Bibinagar. For the study 100 member are taken randomly. Distributed the questionnaire and personal interviews have been carried with observational study. As per the study the object is farmed "to study the economic empowerment of women in Microfinance" and the hypothesis this was tested with the help of frequency table mean median and anova and the following finding have been revealed from the study proving hypothesis rejection". Microfinance shows positive impact on the women empowerment"-rejected.

$>58$ percent of Microfinance member are between the age group of $25-40$.

Majority of the women in this group have completed their secondary education this shows that the members are considerable educated.
$>$ From the study it has been observed that 98 percent of members are above poverty line not after joining Microfinance. As per ANOVA Table 1 shows that there is no effect of joining Microfinance to improve their empowerment.

$>75$ percent of the members are from the Nuclear family there itself shows that they are empowered.

$>$ From the study 95 percent of the member are attending social gatherings these shows there is improved life style.

$>$ The member have control over the loan is 45 percent remaining loan control is done by spouse.

$>$ It has been observed form the study the members are not expose to the violence i.e. 97 percent.

$>100$ percent of the members repaying the loans.

Observed that most of the member the loan allotted to them is given for his spouse helping their business.

\begin{tabular}{|c|c|c|c|}
\hline df & Mean Square & F & Sig \\
\hline 2 & 0.044 & 0.914 & 0.404 \\
\hline 97 & 0.048 & & \\
\hline 99 & & & \\
\hline 2 & 0.002 & 0.173 & 0.842 \\
\hline 97 & 0.010 & & \\
\hline 99 & & & \\
\hline 2 & 0.050 & 0.368 & 0.693 \\
\hline 97 & 0.136 & & \\
\hline 99 & & & \\
\hline 2 & 0.000 & & \\
\hline 97 & 0.000 & & \\
\hline 99 & & & \\
\hline 2 & 1.279 & 1.674 & \\
\hline 97 & 0.764 & & \\
\hline 99 & & & \\
\hline 2 & 0.444 & 0.581 & \\
\hline 97 & 0.763 & & \\
\hline 99 & & & \\
\hline
\end{tabular}

\section{References}

1. Chuler (2005) Gender, Equity and Women's Empowerment: Principles, Definitions and Frameworks.

2. Fouillet C, Augsburg B (2007) Spread of the Self-Help Groups Banking Linkage Programme in India. International Conference on Rural Finance Research pp: 19-21.

3. Jagan EG (2009) Empowerment of women through microfinance and SHGs Microfinance Enabling Empowerment pp: 110-117.

4. Gudaganavar, Rajashri G (2008) Empowerment of Rural Women through SHG. Southern Economist 47: 35-37.

5. Karmakar KG (1999) Rural Credit and Self-help Groups. Microfinance Needs and Concepts in India pp: 374.

6. Kumaraja (2009) Performance of SHG in Tamil Nadu. Southern Economist 47 14-16.

7. Littlefield E, Morduch J, Hashemi S (2003) Is Microfinance are effective strategy to reach the Millennium development Goals? Documents \& Reports.

8. Sabhlok SG (2006) Self Help Groups as a strategy for women's Development in India. University of Melbourne, Australia. 